\title{
Estimating the carbon dynamics of South Korean forests from 1954 to 2012
}

\author{
J. Lee ${ }^{1}$, T. K. Yoon ${ }^{1}$, S. Han ${ }^{1}$, S. Kim ${ }^{1}$, M. J. Yi ${ }^{2}$, G. S. Park ${ }^{3}$, C. Kim ${ }^{4}$, Y. M. Son ${ }^{5}$, R. Kim ${ }^{5}$, and Y. Son ${ }^{1,6,7}$ \\ ${ }^{1}$ Department of Environmental Science and Ecological Engineering, Graduate School, Korea University, Seoul, Korea \\ ${ }^{2}$ Department of Forest Resources, Kangwon National University, Chuncheon, Korea \\ ${ }^{3}$ Department of Environment and Forest Resources, Chungnam National University, Daejeon, Korea \\ ${ }^{4}$ Department of Forest Resources, Gyeongnam National University of Science and Technology, Jinju, Korea \\ ${ }^{5}$ Department of Forest and Climate Change, Korea Forest Research Institute, Seoul, Korea \\ ${ }^{6}$ River Basin Research Center, Gifu University, Gifu, Japan \\ ${ }^{7}$ Department of Biological and Environmental Sciences, Qatar University, Doha, Qatar
}

Correspondence to: Y. Son (yson@korea.ac.kr)

Received: 28 February 2014 - Published in Biogeosciences Discuss.: 31 March 2014

Revised: 22 June 2014 - Accepted: 22 July 2014 - Published: 3 September 2014

\begin{abstract}
Forests play an important role in the global carbon (C) cycle, and the South Korean forests also contribute to this global C cycle. While the South Korean forest ecosystem was almost completely destroyed by exploitation and the Korean War, it has successfully recovered because of nationalscale reforestation programs since 1973. There have been several studies on the estimation of $\mathrm{C}$ stocks and balances over the past decades in the South Korean forests. However, a retrospective long-term study that includes biomass and dead organic matter $\mathrm{C}$ and validates dead organic matter $\mathrm{C}$ is still lacking. Accordingly, we estimated the $\mathrm{C}$ stocks and their changes of both biomass and dead organic matter $\mathrm{C}$ during the 1954-2012 period using a process-based model, the Korean Forest Soil Carbon model, and the 5th South Korean national forest inventory (NFI) report. Validation processes were also conducted based on the 5th NFI and statistical data. Simulation results showed that the biomass C stocks increased from 36.4 to $440.4 \mathrm{Tg} \mathrm{C}$ at a rate of 7.0 Tg $\mathrm{C} \mathrm{yr}^{-1}$ during the period 1954-2012. The dead organic matter $\mathrm{C}$ stocks increased from 386.0 to $463.1 \mathrm{Tg} \mathrm{C}$ at a rate of $1.3 \mathrm{Tg} \mathrm{Cyr}^{-1}$ during the same period. The estimates of biomass and dead organic matter $\mathrm{C}$ stocks agreed well with observed $\mathrm{C}$ stock data. The annual net biome production (NBP) during the period 1954-2012 was $141.3 \mathrm{~g}$ $\mathrm{C} \mathrm{m}^{-2} \mathrm{yr}^{-1}$, which increased from $-8.8 \mathrm{~g} \mathrm{C} \mathrm{m}^{-2} \mathrm{yr}^{-1}$ in 1955 to $436.6 \mathrm{~g} \mathrm{C} \mathrm{m}^{-2} \mathrm{yr}^{-1}$ in 2012. Because of the small forested area, the South Korean forests had a comparatively
\end{abstract}

lower contribution to the annual $\mathrm{C}$ sequestration by global forests. In contrast, because of the extensive reforestation programs, the NBP of South Korean forests was much higher than those of other countries. Our results could provide the forest $\mathrm{C}$ dynamics in South Korean forests before and after the onset of reforestation programs.

\section{Introduction}

Forests contain much carbon $(\mathrm{C})$ in vegetation and soils, and play an important role in the global C cycle (Dixon et al., 1994; Pan et al., 2011). The Kyoto Protocol encouraged the promotion of sustainable forest management practices and the contribution of forests to global $\mathrm{C}$ sequestration has been recognized (IPCC, 2003; UNFCCC, 1997). Consequently, studies on the $\mathrm{C}$ budget of forest biomass and dead organic matter have been conducted to understand temporal forest $\mathrm{C}$ stocks and balances (Bellassen et al., 2011; Kurz and Apps, 1999; Luyssaert et al., 2010; Pan et al., 2011; Piao et al., 2012; Stinson et al., 2011; Wang et al., 2007). Furthermore, to display the net $\mathrm{C}$ changes in forest ecosystems, the net biome production (NBP), defined as net ecosystem production (NEP) minus disturbance loss and leaching, was also estimated (Luyssaert et al., 2010; Stinson et al., 2011).

To estimate the $\mathrm{C}$ stock and balance in forests, inventorybased estimation has been generally used because it estimates 
$\mathrm{C}$ stock and net $\mathrm{C}$ balance directly. However, it has some limitations, such as not providing an annual $\mathrm{C}$ budget, not necessarily taking into account dead organic matter $\mathrm{C}$, and placing limitations on extrapolation due to high spatial variability (Fang et al., 2014; Piao et al., 2012; Wang et al., 2007). Recently, process-based modeling has been used for long-term simulations to provide the annual $\mathrm{C}$ budget of forests and to estimate $\mathrm{C}$ budget beyond the investigated area (Bellassen et al., 2011; Stinson et al., 2011; Wang et al., 2007).

The C dynamics of South Korean forests have varied largely. South Korean forests experienced severe deforestation over the 35 years of Japanese colonization (1910-1945) and the subsequent Korean War (1950-1953) (Kang, 1998; Tak and Wood, 2007). Since 1973, following these periods of serious deforestation, the South Korean government implemented national plantation programs for the recovery of forests. After about 30 years of effort, South Korean forests have successfully recovered and the stocking volume increased from $8.2 \mathrm{~m}^{3} \mathrm{ha}^{-1}$ in 1954 to $125.6 \mathrm{~m}^{3} \mathrm{ha}^{-1}$ in 2010 (Korea Forest Service, 2000, 2011).

Studies on the $\mathrm{C}$ stocks and balances over the past decades in South Korean forests have been conducted for many years. Based on the national forest inventory (NFI) and statistical data, the biomass C stocks of South Korean forests over the past decades were estimated (Choi and Chang, 2004; Fang et al., 2014; Li et al., 2010). While this approach could determine the net $\mathrm{C}$ change in biomass, dead organic matter $\mathrm{C}$ stocks were excluded due to the lack of observed dead organic matter $\mathrm{C}$ stock data. Using the model, the $\mathrm{C}$ balances of South Korean forests were estimated (Piao et al., 2012; Yoo et al., 2013). However, there are some limitations, such as (1) a relatively short simulation period of not more than 2 decades, (2) estimating $\mathrm{C}$ fluxes, not stocks, and (3) insufficient validation of dead organic matter $\mathrm{C}$.

The primary objective of this study was to estimate the $\mathrm{C}$ stocks and their changes in South Korean forests, including biomass and dead organic matter during the post-war period (1954-2012), using the Korean Forest Soil Carbon model (KFSC; Yi et al., 2013) and the 5th South Korean NFI as input data. To estimate the effect of reforestation programs, we provided the annual $\mathrm{C}$ balance and NBP of South Korean forests before and after the onset of those programs. The estimated biomass and dead organic matter $\mathrm{C}$ stocks were validated by comparing them with the observed data in the 5th NFI and statistical data. Furthermore, we compared the annual C balance and NBP of South Korean forests with those of major countries and global forests.

\section{Materials and methods}

\subsection{The 5th South Korean NFI data}

We used the 5th South Korean NFI data to prepare input data for the KFSC model and to validate the estimated dead organic matter C stocks. The latest NFI applied systematic cluster sampling for surveys at intervals of $4 \mathrm{~km}$ along the longitude and latitude ( 1 or $2 \mathrm{~km}$ for small forested areas), and obtained data from approximately 4000 plots during the period 2006-2010 (Korea Forest Research Institute, 2011). It provides information about forest type, species composition, diameter at breast height (DBH), age class, stand density, topographical factors, observed C stocks of pools, and other data of each sampling plot. Each simulation unit represents a forest grid cell of $1 \mathrm{~km} \times 1 \mathrm{~km}$ (43 cells), $2 \mathrm{~km} \times 2 \mathrm{~km}(241$ cells), or $4 \mathrm{~km} \times 4 \mathrm{~km}$ (3606 cells). To upscale the plot-level data to the forest grid cells, the plot-level data were extrapolated and averaged to each forest grid cell. As denuded and bamboo forests were excluded in the simulation, 3890 cells (5870300 ha) were selected from the entirety of the South Korean forests.

\subsection{The KFSC model}

\subsubsection{Model description}

The KFSC model is an empirical and dynamic soil C model that consists of the five biomass compartments (stem, branch, foliage, coarse root, and fine root), five primary dead organic matter compartments (aboveground woody debris from stem, aboveground woody debris from branch, aboveground litter, belowground woody debris, and belowground litter), and three secondary dead organic matter compartments (aboveground humus, belowground humus, and soil organic C) classified according to the degree of decomposition and kinetics (Fig. 1). This model simulates forest $\mathrm{C}$ processes as follows: atmospheric $\mathrm{C}$ is converted to biomass, biomass becomes input to primary dead organic matter pools as litter and woody debris, litter and woody debris are decayed to humus (aboveground and belowground humus), humus is decayed to soil organic $\mathrm{C}$, and soil organic $\mathrm{C}$ is decayed to atmospheric C (Yi et al., 2013). Harvest is considered to be the only disturbance in the model. The performances of the KFSC model are described and validated in Park et al. (2013) and Yi et al. (2013). We parameterized the model for three needleleaf species (Pinus densiflora, P. rigida, and Larix kaempferi) and three broadleaf species (Quercus variabilis, Q. mongolica, and Q. acutissima).

To simulate the biomass $\mathrm{C}$ stocks, we followed the processes as follows: estimation of the growth of stemwood volume, conversion of stemwood volume to $\mathrm{C}$ stocks, and estimation of $\mathrm{C}$ stocks of other biomass compartments (branch, foliage, coarse root, and fine root). First, based on a yield table (Korea Forest Service, 2009), the growth functions of stemwood volume for each species and site index were parameterized using the Gompertz function (Appendix Table A1). An observed stemwood volume was assumed to follow the nearest stemwood growth function and site index. To calibrate the difference between the estimated stemwood volume from a selected growth function and the observed 
stemwood volume in the 5th NFI data for each stand, we multiplied the growth modifier used in Yi et al. (2013) with a selected growth function. The following equation describes the growth modifier used:

$$
\text { Growth modifier }=\frac{\mathrm{Vol}_{\mathrm{obs}}}{\mathrm{Vol}_{\mathrm{est}}} \text {, }
$$

where $\mathrm{Vol}_{\mathrm{obs}}$ is the observed volume of each stand in the 5th NFI data and Volest is the estimated volume of each stand from the estimated growth model. Second, by multiplying the estimated volume with wood density $(0.474,0.508,0.452$, $0.720,0.728$, and $0.707 \mathrm{~g} \mathrm{~cm}^{-3}$ for $P$. densiflora, P. rigida, L. kaempferi, $Q$. variabilis, $Q$. mongolica, and $Q$. acutissima, respectively; Korea Forest Research Institute, 2010) and $\mathrm{C}$ concentration $(50 \%)$, the $\mathrm{C}$ stocks of stemwood were estimated. Third, the other compartments of biomass were calculated by multiplying the $\mathrm{C}$ stocks of stemwood with biomass conversion factors (BCFs), which describe the ratio of branch, foliage, and coarse root to stemwood and are shown in Appendix Table B1. Since the growth of fine root has been poorly studied for these species in Korea, Yi et al. (2013) used the ratio of fine root to foliage described by Vanninen et al. (1996) as shown in Eq. (2):

Fine root $/$ Foliage ratio $=0.0016 \times$ Stand age

$+0.1012\left(r^{2}=0.67\right)$.

For the needleleaf species, this ratio was multiplied with the $\mathrm{C}$ stocks of the foliage to estimate the $\mathrm{C}$ stocks of fine root. Since the growth function of fine root in South Korean forests was unavailable, the static ratio of fine root to coarse root (11:89; Millikin and Bledsoe, 1999) was used to estimate $\mathrm{C}$ stocks of fine root for broadleaf species. By multiplying this ratio with the estimated $\mathrm{C}$ stocks of the coarse root, we estimated $\mathrm{C}$ stocks of the fine root. The dead organic matter $\mathrm{C}$ dynamics are the same as described by Yi et al. (2013); the detailed description of the dead organic matter $\mathrm{C}$ dynamics in the KFSC model is given in Yi et al. (2013).

\subsubsection{Input data and parameters}

The required input data consisted of representative species, site index, growth modifier, forest age, and mean air temperature of each grid cell. The representative species was determined as the tree species occupying the largest basal area $\left(\mathrm{m}^{2}\right)$ in each sampling plot. We used the forest age of each plot from the 5th NFI tree-ring data. For the plots without tree-ring data, the forest age was assumed to be 5, 15, 25, 35, 45 , and 55 for age class I, II, III, IV, V, and VI, respectively, as reported in the 5th NFI data. The mean air temperature of each grid cell was the average of the observed mean annual temperature from 1971 to 2000 from 75 weather stations over South Korea. It was interpolated with a $0.01^{\circ}(\sim 1 \mathrm{~km})$ grid size by the Kriging method, taking into consideration the temperature lapse rate by elevation (Choi et al., 2011;

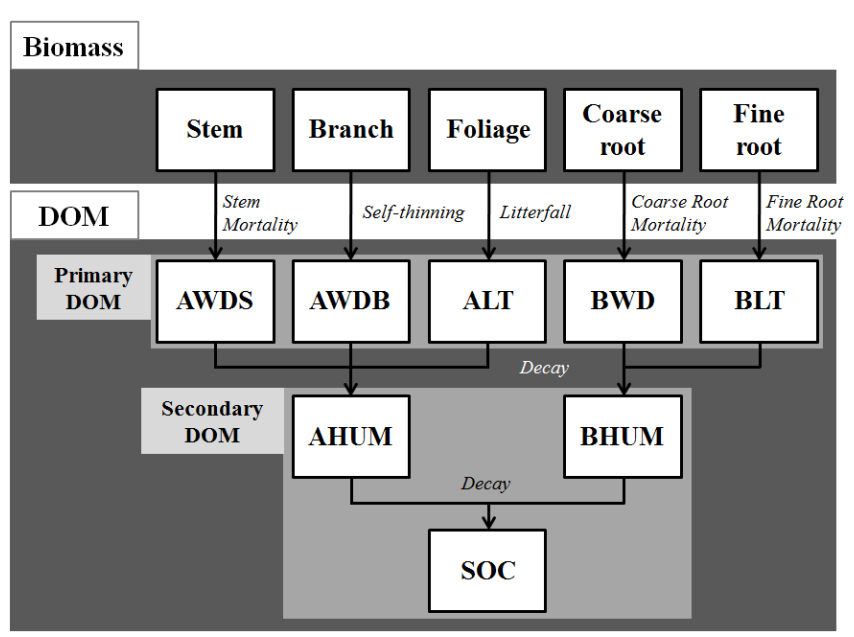

Figure 1. The schematic diagram of the modified forest soil dynamics model (KFSC) used in this study. The carbon pools consist of biomass compartments (stem, branch, foliage, coarse root, and fine root), primary dead organic matter (DOM) compartments (aboveground woody debris from stem (AWDS), aboveground woody debris from branch (AWDB), aboveground litter (ALT), belowground woody debris (BWD), and belowground litter (BLT)), and secondary DOM compartments (aboveground humus (AHUM), belowground humus (BHUM), and soil organic carbon (SOC)). The carbon flows are shown as solid arrows. In Yi et al. (2013), the AWDS and AWDB, as well as the AHUM and BHUM were united as aboveground woody debris (AWD) and humus (HUM), respectively.

Lee et al., 2007). The turnover rates of biomass $C$ pools and decay rates of dead organic matter $\mathrm{C}$ pools were required to simulate forest $\mathrm{C}$ processes (Table 1). The decay rate of aboveground litter and turnover rates of branch and foliage were estimated by 2 years of field work data from 54 plots throughout South Korea (Lee et al., unpublished). The others were cited from other studies (Kim, 2002; Kurz et al., 1992; Liski et al., 2005; Noh, 2011; Park et al., 2006, 2010; Yoon et al., 2011). A detailed description of the modeling processes is given in Yi et al. (2013).

\subsection{Simulation}

\subsubsection{Model initialization and simulation}

The method of reconstructing the forest age distribution is important for accurate simulation (Bellassen et al., 2011; Wang et al., 2007). Due to the lack of age information over the past decades, the forest $\mathrm{C}$ dynamics of each grid cell in South Korea during the period 1954-2012 were simulated by two scenarios, the spin-up scenario and the forest recovery scenario, reconstructing the forest age of each grid cell based on the recent age information in the 5th NFI. The spin-up scenario was applied to some stable stands during the simulation period and the recovery scenario was applied to most 

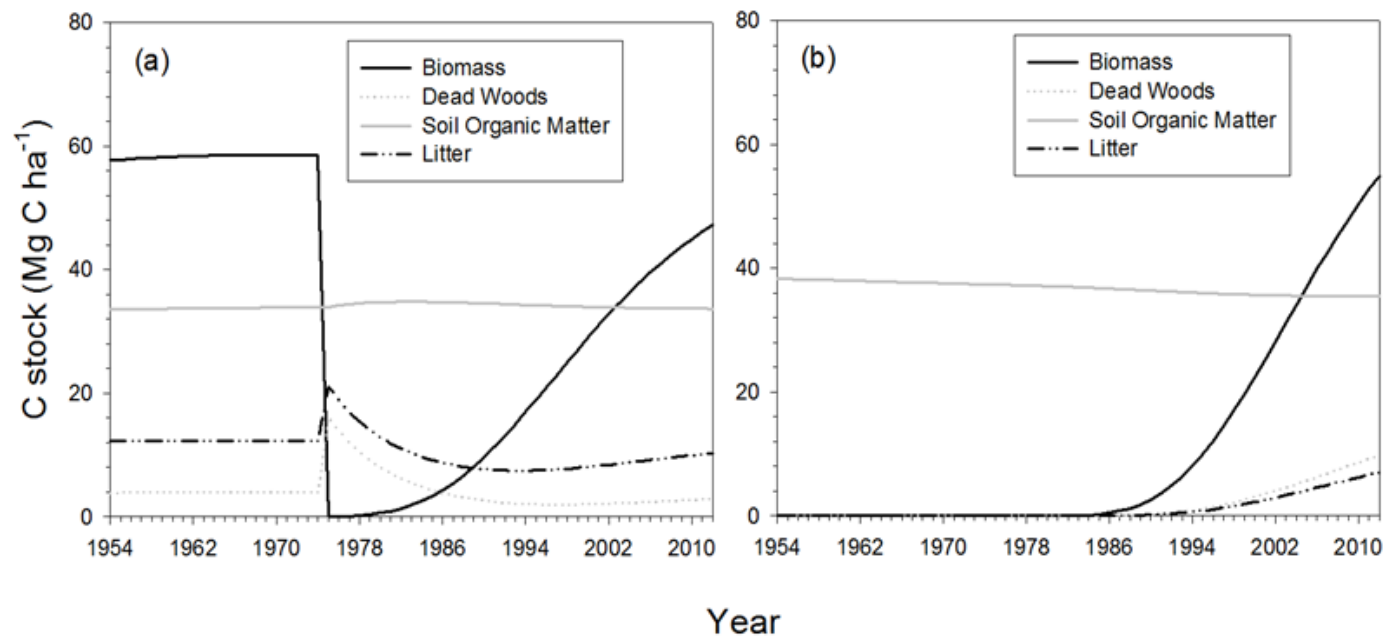

Figure 2. Examples showing the carbon dynamics (biomass, dead woods, soil organic matter, and litter) simulation for each scenario; spin-up scenario (a) and forest recovery scenario (b). The spin-up scenario simulates carbon dynamics under periodic harvesting. The forest recovery scenario simulates carbon dynamics from deforestation. In this scenario, forest carbon stocks start increasing as the forest stand regenerates.

stands that experienced severe deforestation due to exploitation and war.

The 265 forest grid cells simulated by the spin-up scenario were initialized by a spin-up process until the quasi-steady state, such that the difference in the $\mathrm{C}$ stocks of soil organic $\mathrm{C}$ between two successive iterations was $<1 \%$ (Fig. 2a). After that, the model simulated forest $\mathrm{C}$ processes by forest age in 2012. In the forest recovery scenario, 3625 grid cells that experienced severe deforestation were also initialized by the spin-up process, while all dead organic matter $\mathrm{C}$ pools, except soil organic $\mathrm{C}$, were assumed to be zero in 1954, taking into consideration land degradation caused by severe deforestation (Fig. 2b). Then, regeneration was assumed to be suppressed until the recent regeneration. Soil organic $\mathrm{C}$ continued to decay slowly until the vegetation recovered sufficiently. As the vegetation recovered, biomass and dead organic matter input started increasing. The forest grid cells simulated by the spin-up scenario were determined by the following criteria: (1) the stands regenerated before 1954 (over 60 years old), or (2) a stand located at the highest elevation for each forest age and province (Gangwon, Chungbuk, Chungnam, Chonnam, and Gyungbuk) from which the highest volume was harvested during the period 1970-2010 (Korea Forest Service, 1974, 1988, 2000, 2005, 2010, 2012). These criteria assumed that stands that were old and located at high altitudes were not disturbed by exploitation and war. The other stands were assumed to have been severely destroyed, and were thus simulated by the forest recovery scenario.

\subsubsection{Calculation of forest $\mathrm{C}$ stock, annual $\mathrm{C}$ balance, and NBP}

To calculate the $\mathrm{C}$ stocks of the biomass and dead organic matter pools in South Korean forests, we applied Eq. (3):

C stock $(\mathrm{Mg} \mathrm{C})=\sum_{k=1}^{3890}$ mean C density $\left(\mathrm{Mg} \mathrm{C} \mathrm{ha}^{-1}\right)$

$\times A_{k}$ (ha)

where $k$ is the identification number of each sampling plot, mean $\mathrm{C}$ density is the simulated biomass or dead organic matter $\mathrm{C}$ per hectare, and $A$ is the size of the grid cell, including each sampling plot.

The annual $\mathrm{C}$ balance and NBP were calculated to estimate the change in $\mathrm{C}$ stocks in South Korean forests. The annual $\mathrm{C}$ balance $\left(\mathrm{Tg} \mathrm{Cyr}^{-1}\right)$ was defined as the annual change in $\mathrm{C}$ stocks in the entire South Korean forest ecosystem. In contrast, the NBP $\left(\mathrm{g} \mathrm{C} \mathrm{m}^{-2} \mathrm{yr}^{-1}\right)$ is generally defined as the net primary production minus the heterotrophic respiration and the disturbances (fire, harvest, pests, land-use change, and other disturbances), and represents an average of the net ecosystem $\mathrm{C}$ balance over space and time (Chapin et al., 2006). In South Korea, because of the extensive management of insect populations and negligible damage by forest fire ( $<5 \%$ of annually harvested stemwood volume), the disturbances such as insects and fires could be ignored (Korea Forest Service, 1985, 1997, 2002, 2012). As 80-year-interval clear-cut was assumed to be the only disturbance and landuse change was not considered in this study, this model could simulate the net change of $\mathrm{C}$ stocks in the forest biome. To calculate the NBP of South Korean forests during certain period, the change in $\mathrm{C}$ stocks in South Korean forests were 
Table 1. Standard input parameter values for model simulation. The other parameters are the same as described by Yi et al. (2013).

\begin{tabular}{lll}
\hline Parameters & Values & Notes \\
\hline Turnover rate $\left(y r^{-1}\right)$ & & \\
Stem & $0.002^{\mathrm{a}, \mathrm{b}, \mathrm{c}}$ & Noh (2011) \\
& $0.0045^{\mathrm{d}, \mathrm{e}, \mathrm{f}}$ & Kurz et al. (1992) \\
Branch & $0.061^{\mathrm{a}, \mathrm{b}, \mathrm{c}}$ & Lee et al. (unpublished) \\
& $0.057^{\mathrm{d}, \mathrm{e}, \mathrm{f}}$ & Lee et al. (unpublished) \\
Foliage & $0.385^{\mathrm{a}, \mathrm{b}}$ & Lee et al. (unpublished) \\
& $0.934^{\mathrm{c}, \mathrm{d}, \mathrm{e}, \mathrm{f}}$ & Lee et al. (unpublished) \\
Coarse roots & 0.02 & Kurz et al. (1992) \\
Fine roots & $1.23^{\mathrm{a}, \mathrm{b}, \mathrm{c}}$ & Park et al. (2010) \\
& $0.695^{\mathrm{e}}$ & Park et al. (2006) \\
& $1.195^{\mathrm{d}, \mathrm{f}}$ & Park et al. (2006) \\
\hline Decay constant $\left(y r^{-1}\right)$ & & \\
AWDS and AWDB & $0.137^{\mathrm{a}, \mathrm{b}, \mathrm{c}}$ & Noh (2011) \\
& $0.058^{\mathrm{d}, \mathrm{e}, \mathrm{f}}$ & Yoon et al. (2011) \\
ALT & $0.317^{\mathrm{a}, \mathrm{b}, \mathrm{c}}$ & Lee et al. (unpublished) \\
& $0.402^{\mathrm{d}, \mathrm{e}, \mathrm{f}}$ & Lee et al. (unpublished) \\
BWD & $0.137^{\mathrm{a}, \mathrm{b}, \mathrm{c}}$ & Assumed to be equal to the decay constant of AWD \\
& $0.058^{\mathrm{d}, \mathrm{e}, \mathrm{f}}$ & Assumed to be equal to the decay constant of AWD \\
BLT & 0.462 & Kim (2002) \\
AHUM and BHUM & $0.012^{\mathrm{a}, \mathrm{b}, \mathrm{c}}$ & Liski et al. (2005): standard value for fast HUM pool \\
& $0.02^{\mathrm{d}, \mathrm{e}, \mathrm{f}}$ & Liski et al. (2005): maximum value for fast HUM pool \\
& $0.0012^{\mathrm{a}, \mathrm{b}, \mathrm{c}}$ & Liski et al. (2005): standard value for fast HUM pool \\
& $0.0017^{\mathrm{d}, \mathrm{e}, \mathrm{f}}$ & Liski et al. (2005): maximum value for fast HUM pool \\
\hline
\end{tabular}

${ }^{\text {a }}$ Pinus densiflora,${ }^{\mathrm{b}}$ P. rigida, ${ }^{\mathrm{c}}$ Larix kaempferi, ${ }^{\mathrm{d}}$ Quercus variabilis, ${ }^{\mathrm{e}}$ Q. mongolica,,${ }^{\mathrm{f}}$ Q. acutissima.

divided by the total simulation area ( 5870300 ha) and the corresponding period (yr).

\subsubsection{Model validation}

We validated the estimated biomass and dead organic matter $\mathrm{C}$ stocks by comparing the estimated values to observed values from the statistical data and the 5th NFI data. For biomass, the estimates of stocking volume on a national scale during the period 1954-2010 were compared to the Statistical Yearbook of Forestry (Korea Forest Service, 2000, 2011) to indirectly validate the estimated biomass $\mathrm{C}$ stocks. Since observed data for dead organic matter $\mathrm{C}$ from the past does not exist, the dead organic matter $\mathrm{C}$ stocks in the 5th NFI data were used to validate the estimates. The estimates of $\mathrm{C}$ stocks in soil layers (belowground humus + soil organic C) were multiplied by 0.6 (Lee et al., 2009) for comparison with the observed data, which was sampled at $0-30 \mathrm{~cm}$ depths. The estimates of other dead organic matter values, excluding dead woods (aboveground woody debris from stem, belowground woody debris, and belowground litter; data are unavailable in the 5th NFI), were added to those of soil $\mathrm{C}$ for validation. The performance of the model in predicting dead organic matter $\mathrm{C}$ stocks was analyzed using the root mean square error (RMSE).

\section{Results and discussion}

\subsection{The $\mathrm{C}$ stocks and annual $\mathrm{C}$ balances of biomass}

An increase in the $\mathrm{C}$ stock of biomass in South Korean forests was observed, with the data increasing from $36.4 \mathrm{Tg} \mathrm{C}$ in 1954 to $440.4 \mathrm{Tg} \mathrm{C}$ in 2012 (Fig. 3). The annual $\mathrm{C}$ bal-

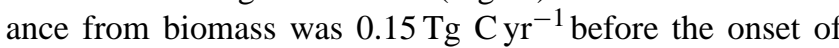
reforestation programs (1954-1973). The annual $\mathrm{C}$ balance of biomass was higher at a rate of $10.3 \mathrm{Tg} \mathrm{C} \mathrm{yr}^{-1}$ after the onset of those programs (1974-2012). Averaged over the entire 1954-2012 period, the annual $\mathrm{C}$ balance of biomass was 7.0 $\mathrm{Tg} \mathrm{C} \mathrm{yr}^{-1}$.

The estimated stocking volumes simulated by the KFSC model were compared with observed stemwood volume data to indirectly validate the estimated biomass $\mathrm{C}$ stocks. The time series of estimated stocking volume showed a similar trend to that of observed stocking volumes on a national scale $\left(r^{2}=0.98\right.$; Fig. 4). According to the Statistical Yearbook of Forestry (Korea Forest Service, 2000, 2011), the stocking volume in South Korean forests increased from 51.8 to $800.0 \mathrm{Mm}^{3}$ between 1954 and 2010 . The simulation result showed that it increased from 78.4 to $798.0 \mathrm{Mm}^{3}$ during that period. This implied the successful reconstruction of age 
Table 2. Comparison of biomass carbon (C) density, biomass C stocks, and annual C balance rate of South Korean forests with those of two previous studies.

\begin{tabular}{llll}
\hline Category & Year or period & Estimate & Reference \\
\hline Mean C density $\left(\mathrm{Mg} \mathrm{Cha}^{-1}\right)$ & 1954 & 4.3 & Li et al. (2010) \\
& 1954 & 6.2 & This study \\
& 2001 & 34.4 & Choi and Chang (2004) \\
Biomass C stock (Tg C) & 2001 & 39.7 & This study \\
& 1954 & 20.6 & Li et al. (2010) \\
& 1954 & 36.4 & This study \\
& 2001 & 221.0 & Choi and Chang (2004) \\
& 2001 & 233.3 & This study \\
& 2007 & 239.9 & Li et al. (2010) \\
& 2007 & 341.1 & This study \\
& $1993-2007$ & 9.1 & Li et al. (2010) \\
& $1993-2007$ & 15.5 & This study \\
& $1997-2001$ & 9.6 & Choi and Chang (2004) \\
& $1997-2001$ & 15.6 & This study \\
\hline
\end{tabular}

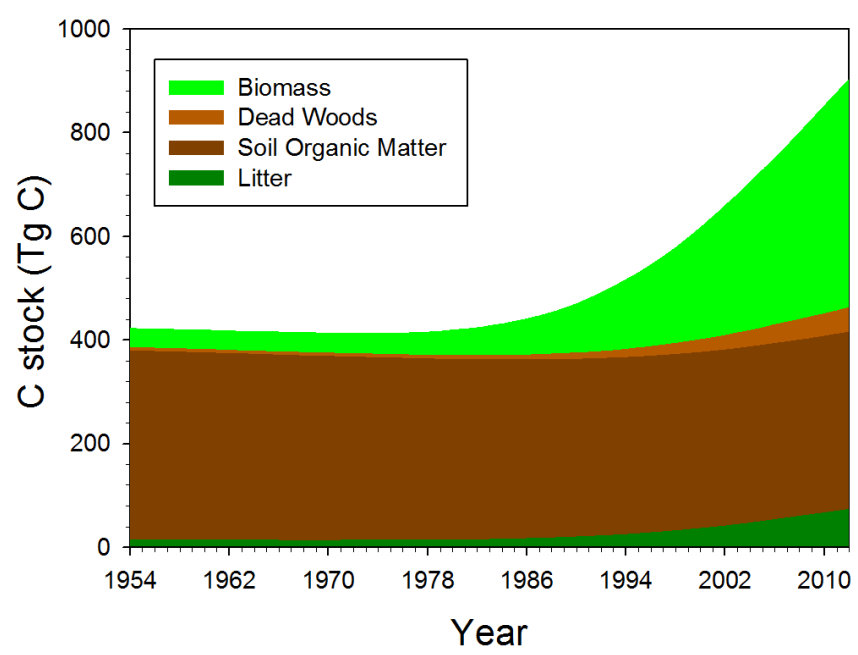

Figure 3. The time series of biomass and dead organic matter (dead woods, soil organic matter, and litter) carbon (C) stocks in South Korean forests during the simulation period. Total C stocks in South Korea have increased as forest vegetation has recovered.

distribution on a national scale, while it was still uncertain on a stand scale.

Our finding was consistent with other studies showing a large increase in biomass $\mathrm{C}$ stocks after the onset of reforestation programs. However, the mean biomass $\mathrm{C}$ density, biomass $\mathrm{C}$ stock, and annual $\mathrm{C}$ balance in this study were estimated higher than other studies (Table 2). There were two possible reasons explaining these differences. As shown in Fig. 4, the stocking volume simulated by the model in recent years was an overestimate compared to the observed stocking volume. This caused the higher estimates of recent mean biomass $\mathrm{C}$ density and stocks, and annual $\mathrm{C}$ balance. The other possible reason was a difference in the methods of biomass $\mathrm{C}$ stock estimation. We estimated the biomass $\mathrm{C}$ stocks with species-specific growth functions and BCFs (biomass conversion factors). In contrast, Li et al. (2010) and Choi and Chang (2004) estimated the biomass C stocks by multiplying stemwood volume with forest type-specific (coniferous, deciduous, and mixed) and constant biomass expansion factors (BEFs). Variable BEFs could overestimate biomass $\mathrm{C}$ of a young forest compared to constant BEFs (Guo et al., 2010). As South Korean forests are relatively young, the estimated biomass $\mathrm{C}$ stocks of South Korean forests with BCFs could be higher than the estimates with constant BEFs. As the ratio of each compartment in biomass varied with stand age, our estimates would be considered more realistic.

\subsection{The $\mathrm{C}$ stocks and annual $\mathrm{C}$ balances of dead organic matter}

An increase in the C stock of dead organic matter in South Korean forests was also observed, with the data increasing from 386.0 Tg C in 1954 to $463.1 \mathrm{Tg} \mathrm{C}$ in 2012 (Fig. 3). Before the onset of reforestation programs, the $\mathrm{C}$ stock of dead organic matter was $\mathrm{C}$ source releasing $\mathrm{C}$ at a rate of $0.7 \mathrm{Tg}$

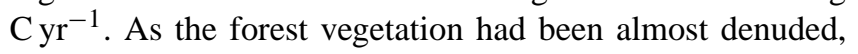
the decomposition of the dead organic matter $\mathrm{C}$ exceeded the dead organic matter input during that period. Until around 1980, the dead organic matter C stocks were a C source. After the onset of reforestation programs and the recovery of litter input, the $\mathrm{C}$ stocks of dead organic matter changed from a $\mathrm{C}$ source to a $\mathrm{C}$ sink, sequestering $\mathrm{C}$ at a rate of $2.3 \mathrm{Tg}$

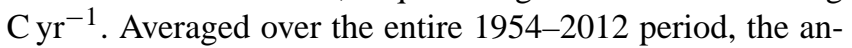

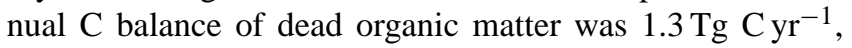
which was approximately $20 \%$ of that of biomass $(7.0 \mathrm{Tg}$ $\left.\mathrm{C} \mathrm{yr}^{-1}\right)$. 
Table 3. The estimates of annual carbon (C) sink and net biome production (NBP) in South Korean forests compared to those in past studies from other countries.

\begin{tabular}{|c|c|c|c|c|c|c|}
\hline \multirow[t]{2}{*}{ Region } & \multirow[t]{2}{*}{ Period } & \multicolumn{2}{|c|}{ Annual $\mathrm{C}$ sink $\left(\mathrm{Tg} \mathrm{C} \mathrm{yr}^{-1}\right)$} & \multicolumn{2}{|c|}{$\mathrm{NBP}\left(\mathrm{g} \mathrm{C} \mathrm{m}^{-2} \mathrm{yr}^{-1}\right)$} & \multirow[t]{2}{*}{ Reference } \\
\hline & & Biomass & DOM & Biomass & DOM & \\
\hline Canada & 1929-1989 & 14.8 & 50.7 & 12.4 & 36.0 & Kurz and Apps (1999) \\
\hline \multirow[t]{2}{*}{ Europe } & 1950-1999 & 49.0 & 30.0 & 35.0 & 21.4 & Nabuurs et al. $(2003)^{b}$ \\
\hline & 1995-2005 & 80.0 & 29.0 & 53.0 & 22.0 & Luyssaert et al. (2010) \\
\hline \multirow[t]{2}{*}{ United States } & 1990-1999 & 118 & 28 & 47 & 11 & Pan et al. $(2011)^{\mathrm{c}}$ \\
\hline & 2000-2007 & 147 & 64 & 58 & 25 & \\
\hline \multirow[t]{2}{*}{ China } & 1990-1999 & 60 & 68 & 43 & 48 & \\
\hline & 2000-2007 & 115 & 60 & 77 & 40 & \\
\hline \multirow[t]{2}{*}{ Global forests } & 1990-1999 & 2991 & 868 & 76 & 22 & \\
\hline & 2000-2007 & 2941 & 887 & 76 & 23 & \\
\hline South Korea & 1954-2012 & 7.0 & 1.3 & 116.7 & 22.6 & This study \\
\hline
\end{tabular}

a To calculate the NBP, C sink was divided by the total change in biomass and dead organic matter (DOM) stocks with 404 Mha. ${ }^{\mathrm{b}}$ To calculate the NBP, the C uptake rate was divided by forest area in $1999 .^{c}$ To calculate the NBP, harvested wood product was excluded in C stock change.

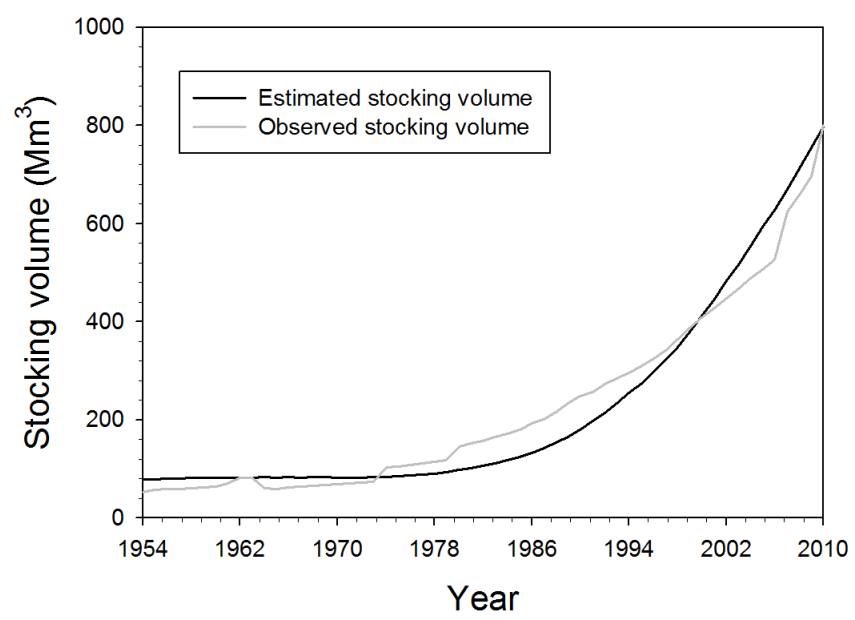

Figure 4. The time series of the estimated and observed (statistical data) stocking volume in South Korean forests during the simulation period. The observed stocking volumes of each year were compiled from those published by the Korea Forest Service in the Statistical Yearbook of Forestry.

The model estimates and NFI inventories for dead organic matter $\mathrm{C}$ stocks were in partial agreement (Fig. 5). The RMSE of the estimates were 26.9 and $49.2 \mathrm{Mg} \mathrm{Cha}^{-1}$ for needleleaf species and broadleaf species, respectively, on a regional scale. The underestimation of dead organic matter $\mathrm{C}$ stocks could be partially explained by the mean air temperature used as input data. As recent air temperature has been higher than that of past centuries (Aizebeokhai, 2009), the decay rates of dead organic matter $\mathrm{C}$ pools might be overestimated for the initialization process. Accordingly, the initial dead organic matter $\mathrm{C}$ stocks were probably underestimated and uncertainties in estimating dead organic matter $\mathrm{C}$ stocks occurred (Peltoniemi et al., 2006; Wutzler and Reichstein, 2007).
Soil type also could affect the decay rate of humus, ultimately the dead organic matter $\mathrm{C}$ dynamics. Because of difference in dominant soil type, the dead organic matter $\mathrm{C}$ stocks of Jeju province might be especially highly underestimated (Fig. 5). Separated from the mainland provinces, Jeju province is a volcanic island and the representative soil type of Jeju is Andisol (Ahn and Chon, 2010). Andisol soils contain more $\mathrm{C}$ stocks than other soil types for two reasons: for the properties of soil organic matter derived from charred plant materials (Shindo et al., 2004) and the low decay rates of soil organic matter caused by the strong combination with allophane (Calabi-Floody et al., 2011; Theng and Yuan, 2008). As the input of these materials by volcanic activities and the low decay rates were not considered in the KFSC model, the dead organic matter C stocks in Jeju province may be underestimated. Excluding Jeju province, the RMSE improved to 12.8 and $21.9 \mathrm{Mg} \mathrm{Cha}^{-1}$ in needleleaf and broadleaf species, respectively. As Jeju province accounts for only $1.8 \%$ of South Korean forests, the estimated $\mathrm{C}$ stocks in South Korean forests might be reliable.

\subsection{The total $\mathrm{C}$ stocks, annual $\mathrm{C}$ balances, and NBPs of South Korean forests}

Increasing total $\mathrm{C}$ stocks were observed. The $\mathrm{C}$ stocks in South Korean forests increased from 422.4 Tg C in 1954 to 903.5 Tg C in 2012. As the $\mathrm{C}$ emission from dead organic matter $\mathrm{C}$ stocks overwhelmed $\mathrm{C}$ sequestration by biomass C stocks in the first 2 decades (1954-1973), South Korean forests were a $\mathrm{C}$ source and released $\mathrm{C}$ at a rate of $0.5 \mathrm{Tg}$

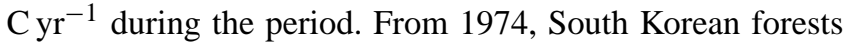
changed from $\mathrm{C}$ source to $\mathrm{C}$ sink, sequestering $\mathrm{C}$ at a rate of $12.6 \mathrm{Tg} \mathrm{Cyr}^{-1}$. Averaged over the entire 1954-2012 pe-

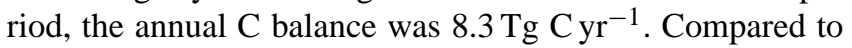
the national fossil-fuel-based $\mathrm{C}$ emissions data during the period 1954-2008 (Boden et al., 2011), South Korean forests 


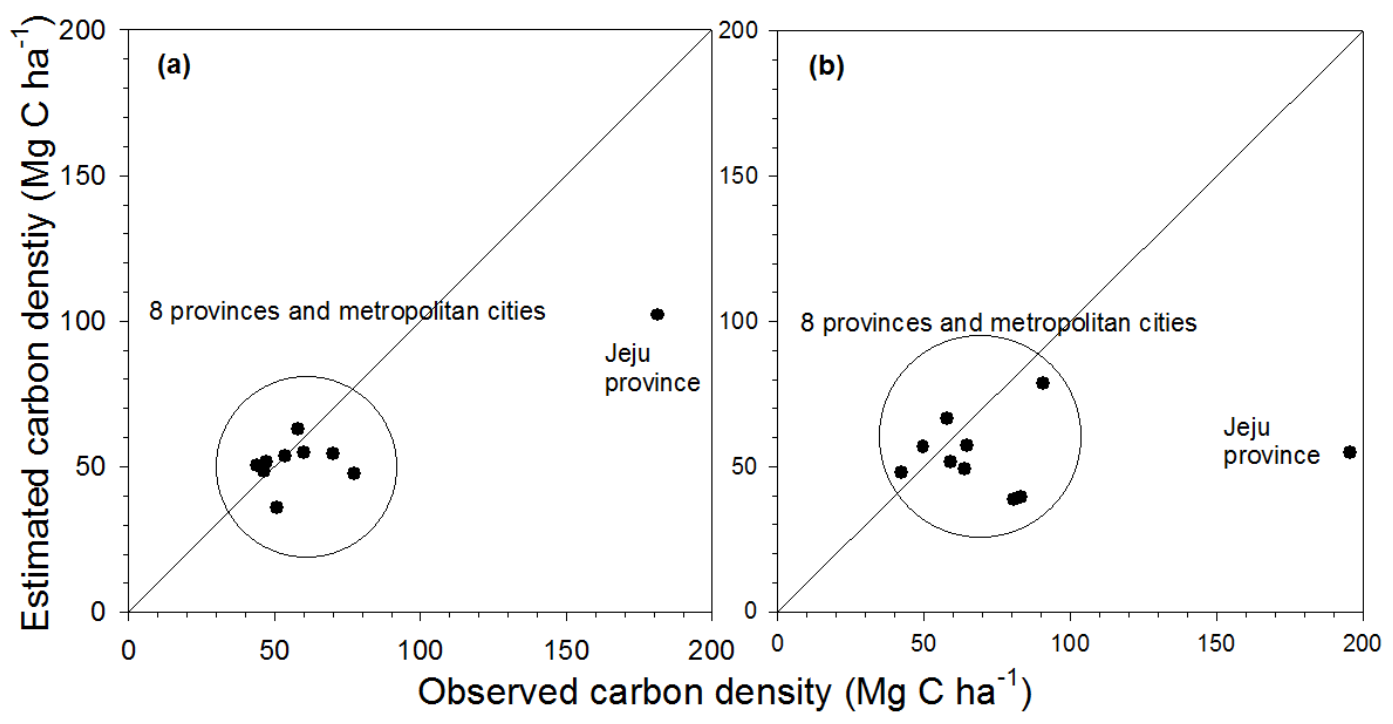

Figure 5. Comparison between the estimated and observed carbon (C) densities of dead organic matter, excluding dead woods for needleleaf species (a) and broadleaf species (b). The $\mathrm{C}$ densities of seven metropolitan cities were compiled as one unit.

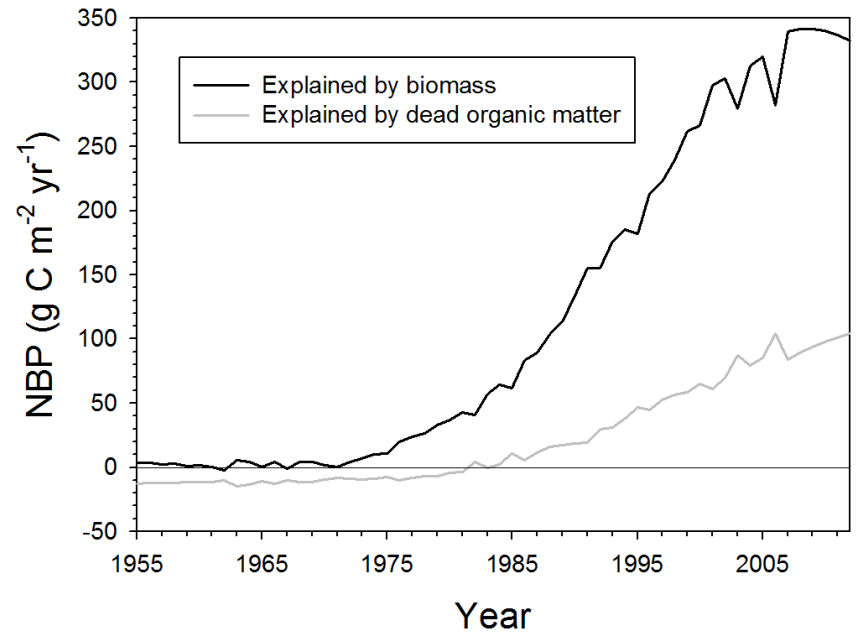

Figure 6. The time series of net biome production (NBP) in South Korean forests during the simulation period. Carbon (C) sequestration by biomass and dead organic matter $\mathrm{C}$ stocks in South Korean forests rapidly increased and showed an upward trend.

annually offset $13.4 \%$ of the South Korean fossil fuel C emissions during that period.

The time series of NBP increased over the simulation period and the change in NBP showed an upward trend (Fig. 6). The NBP during the period 1954-2012 was $141.3 \mathrm{~g}$ $\mathrm{C} \mathrm{m}^{-2} \mathrm{yr}^{-1}$ and that in 1955 and 2012 were estimated to be -8.8 and $436.6 \mathrm{~g} \mathrm{C} \mathrm{m}^{-2} \mathrm{yr}^{-1}$, respectively. The onset of reforestation programs influenced the mean NBP and the averaged NBP was -8.7 and $214.4 \mathrm{~g} \mathrm{C} \mathrm{m}^{-2} \mathrm{yr}^{-1}$, during the 1954-1973 and 1974-2012 periods, respectively. These high NBP values of South Korean forests after the onset of refor- estation programs were attributed to a rapid increment of C stocks in biomass. As two-thirds of the South Korean forests are less than 40 years old (Korea Forest Service, 2013), the $\mathrm{C}$ stocks in biomass could rapidly increase. For example, the annual growth of biomass $\mathrm{C}$ stocks in the forests that are 20-40 years old ranged from 144.0 to $401.4 \mathrm{~g} \mathrm{C} \mathrm{m}^{-2} \mathrm{yr}^{-1}$ for P. densiflora and from 174.5 to $588.3 \mathrm{~g} \mathrm{C} \mathrm{m}^{-2} \mathrm{yr}^{-1}$ for $Q$. variabilis, based on the yield tables and BCFs. Considering that the dead organic matter $\mathrm{C}$ input from biomass also contributed to the NBP, those values could explain the high NBP of South Korean forests. In addition, the empirical study conducted in the mature South Korean forest also indicated a high rate of $\mathrm{C}$ sequestration by forests $\left(418 \mathrm{~g} \mathrm{C} \mathrm{m}^{-2} \mathrm{yr}^{-1}\right.$; Noh et al., 2013).

As the forest vegetation recovered, the contribution of biomass to NBP increased over the simulation period and became higher than that of dead organic matter over that period. The contribution of biomass to NBP increased from 22.9 to $76.1 \%$ during the period 1954-2012, and dead organic matter accounted for the remainder. Although the $\mathrm{C}$ stock of dead organic matter was also a $\mathrm{C}$ sink, that of biomass recently became a more important $\mathrm{C}$ sink in South Korean forests.

We compared the annual C balance and NBP of South Korean forests with those of forests from other countries and global forests (Table 3). Global forests annually sequestered about 3.8 $\mathrm{Pg} \mathrm{C} \mathrm{yr}^{-1}$ (Pan et al., 2011) and South Korean forests accounted for less than $1 \%$ of that $\left(8.3 \mathrm{Tg} \mathrm{C} \mathrm{yr}^{-1}\right)$. However, the NBP of South Korean forests exceeded that of foreign forests, and the global average significantly. The NBP of global forests was around $100 \mathrm{~g} \mathrm{C} \mathrm{m}^{-2} \mathrm{yr}^{-1}$ during the period 1990-2007 and that of South Korean forests during the period 1990-2007 was $365.2 \mathrm{~g} \mathrm{C} \mathrm{m}^{-2} \mathrm{yr}^{-1}$. The NBP of other major countries was also lower than that of South 
Korean forests. This large difference in NBP might be attributed to the extensive reforestation program in a national scale.

\subsection{Uncertainties}

Although we estimated the $\mathrm{C}$ stocks and their changes of South Korean forests including biomass and dead organic matter $\mathrm{C}$, there are still uncertainties in the estimation. A site index, which is important input data for determining the productivity of a forest, seemed to be responsible for the uncertainty. In the KFSC model, the site index is determined by the forest age and observed stemwood volume, based on the yield table. In other process-based models, physiological processes were coupled to simulate the growth of biomass, and various input data (e.g., temperature, $\mathrm{CO}_{2}$ concentration, solar radiation, or precipitation) are required (Chen et al., 2000; Ito et al., 2005; Krinner et al., 2005; Sitch et al., 2003). Using yield tables for a regional scale (Kurz et al., 2009) or quantifying the site index based on environmental factors (Nothdurft et al., 2012; Wang and Klinka, 1996) will help constrain the uncertainties associated with estimating a site index. To enable more precise and comprehensive assessment of South Korean forest $\mathrm{C}$ cycles, some important influences on $\mathrm{C}$ balance, such as $\mathrm{CO}_{2}$ fertilization (Bellassen et al., 2011; Luyssaert et al., 2010), N deposition (Luyssaert et al., 2010), leaching (Luyssaert et al., 2010; Piao et al., 2012), forest area changes (Liski et al., 2006; Nabuurs et al., 2003), and management and other disturbances (Jandl et al., 2007; Kurz et al., 2009; Liu et al., 2002; Luyssaert et al., 2010; Zhou et al., 2013) need to be considered.

\section{Conclusions}

Using a model, we estimated the $\mathrm{C}$ dynamics of South Korean forests between 1954 and 2012. During this period, the total C stocks of South Korean forests increased from 422.4 to $903.5 \mathrm{Tg}$ C. South Korean forests changed from a $\mathrm{C}$ source to a $\mathrm{C}$ sink because of the extensive reforestation. The average annual $\mathrm{C}$ balance during this period was $8.3 \mathrm{Tg}$ $\mathrm{C} \mathrm{yr}^{-1}$ and the NBP was $141.3 \mathrm{~g} \mathrm{C} \mathrm{m}^{-2} \mathrm{yr}^{-1}$. From 1954 to $2008,13.4 \%$ of the fossil fuel $\mathrm{C}$ emission from Korea was offset by $\mathrm{C}$ accumulation in forest ecosystems. Because of the small forested area, South Korean forests had a comparatively lower contribution to the total $\mathrm{C}$ sequestration by global forests. However, the NBP of South Korean forests was much higher than those of other countries. The high NBP is a result of the implementation of extensive reforestation programs after the severe deforestation; thus, extensive reforestation activities after severe deforestation events would contribute to $\mathrm{C}$ sequestration for global climate change mitigation. 


\section{Appendix A}

Table A1. Parameter estimates of the Gompertz function for stem volume $\left(\mathrm{m}^{3} \mathrm{ha}^{-1}\right)$ for six dominant species by site index in Korea. Volume $($ age $)=a \cdot \exp (b \cdot \exp (c \cdot$ age $))$.

\begin{tabular}{lllll}
\hline Species & Site index & $a$ & $b$ & $c$ \\
\hline Pinus densiflora & 10 & 182.8 & -7.73 & -0.0902 \\
& 12 & 231.5 & -8.75 & -0.0954 \\
& 14 & 285.6 & -9.55 & -0.0991 \\
P. rigida & 16 & 345.0 & -10.20 & -0.1018 \\
& 10 & 221.7 & -4.30 & -0.0593 \\
& 12 & 268.2 & -4.85 & -0.0642 \\
& 14 & 322.1 & -4.74 & -0.0637 \\
& 16 & 378.0 & -4.81 & -0.0644 \\
Larix kaempferi & 18 & 436.7 & -4.85 & -0.0649 \\
& 16 & 319.5 & -2.78 & -0.0423 \\
& 18 & 355.2 & -2.79 & -0.0439 \\
& 20 & 393.2 & -2.77 & -0.0450 \\
Quercus variabilis & 22 & 432.4 & -2.75 & -0.0461 \\
& 12 & 472.8 & -2.73 & -0.0470 \\
& 14 & 190.3 & -3.81 & -0.0883 \\
& 16 & 233.6 & -3.90 & -0.0903 \\
Q. mongolica & 18 & 311.5 & -4.01 & -0.0930 \\
& 12 & 268.7 & -2.83 & -0.0422 \\
& 14 & 295.9 & -2.76 & -0.0436 \\
Q. acutissima & 16 & 350.7 & -2.83 & -0.0440 \\
& 16 & 378.5 & -3.48 & -0.0397 \\
& 18 & 411.3 & -3.40 & -0.0406 \\
& 20 & 444.3 & -3.36 & -0.0417 \\
\hline & & & & \\
\hline
\end{tabular}




\section{Appendix B}

Table B1. The biomass conversion factors (BCFs) for each species by site indices. Multiplying BCFs with C stocks of stemwood, C stocks of other compartments were estimated. The estimation method for the parameters is given in Yi et al. (2013). $\mathrm{BCF}(\mathrm{age})=a \cdot \mathrm{age}^{b}$.

\begin{tabular}{|c|c|c|c|c|c|c|c|}
\hline \multirow[t]{3}{*}{ Species } & \multirow[t]{3}{*}{ Site index } & \multicolumn{6}{|c|}{ Compartments } \\
\hline & & \multicolumn{2}{|l|}{ Branch } & \multicolumn{2}{|l|}{ Foliage } & \multicolumn{2}{|c|}{ Coarse root } \\
\hline & & $a$ & $b$ & $a$ & $b$ & $a$ & $b$ \\
\hline \multirow[t]{4}{*}{ Pinus densiflora } & 10 & 0.3574 & -0.1397 & 0.8357 & -0.6735 & 0.3962 & -0.0545 \\
\hline & 12 & 0.3515 & -0.1397 & 0.7772 & -0.6746 & 0.3936 & -0.0545 \\
\hline & 14 & 0.3462 & -0.1396 & 0.7203 & -0.6730 & 0.3912 & -0.0545 \\
\hline & 16 & 0.3419 & -0.1401 & 0.6811 & -0.6754 & 0.3893 & -0.0547 \\
\hline \multirow{5}{*}{ P. rigida } & 10 & 3.1964 & -0.7503 & 4.4212 & -1.1445 & 0.9754 & -0.1301 \\
\hline & 12 & 2.9530 & -0.7532 & 3.9561 & -1.1507 & 0.9599 & -0.1302 \\
\hline & 14 & 2.7372 & -0.7544 & 3.5568 & -1.1543 & 0.9458 & -0.1302 \\
\hline & 16 & 2.5654 & -0.7564 & 3.2363 & -1.1576 & 0.9342 & -0.1305 \\
\hline & 18 & 2.4138 & -0.7577 & 2.9642 & -1.1602 & 0.9233 & -0.1306 \\
\hline \multirow[t]{5}{*}{ Larix kaempferi } & 16 & 1.3883 & -0.5117 & 3.4449 & -1.205 & 0.7175 & -0.1823 \\
\hline & 18 & 1.3124 & -0.5084 & 3.0006 & -1.1902 & 0.7033 & -0.1815 \\
\hline & 20 & 1.2623 & -0.5090 & 2.8055 & -1.1961 & 0.6922 & -0.1815 \\
\hline & 22 & 1.2219 & -0.5105 & 2.6327 & -1.2003 & 0.6832 & -0.1819 \\
\hline & 24 & 1.1854 & -0.5119 & 2.4794 & -1.2041 & 0.6750 & -0.1824 \\
\hline \multirow[t]{4}{*}{ Quercus variabilis } & 12 & 0.0458 & 0.4536 & 0.0907 & -0.2120 & 0.8268 & -0.1060 \\
\hline & 14 & 0.0479 & 0.4529 & 0.0889 & -0.2110 & 0.8181 & -0.1060 \\
\hline & 16 & 0.0500 & 0.4523 & 0.0871 & -0.2110 & 0.8099 & -0.1060 \\
\hline & 18 & 0.0516 & 0.4537 & 0.0858 & -0.2120 & 0.8039 & -0.1060 \\
\hline \multirow[t]{3}{*}{ Q. mongolica } & 12 & 0.0376 & 0.6848 & 0.1139 & -0.1280 & 2.7366 & -0.3750 \\
\hline & 14 & 0.0392 & 0.6836 & 0.1130 & -0.1280 & 2.6765 & -0.3750 \\
\hline & 16 & 0.0406 & 0.6835 & 0.1123 & -0.1280 & 2.6259 & -0.3750 \\
\hline \multirow[t]{3}{*}{ Q. acutissima } & 16 & 0.0676 & 0.5064 & 0.0789 & -0.0380 & 2.0183 & -0.4200 \\
\hline & 18 & 0.0659 & 0.5066 & 0.0788 & -0.0380 & 1.9708 & -0.4200 \\
\hline & 20 & 0.0640 & 0.5074 & 0.0786 & -0.0380 & 1.9293 & -0.4190 \\
\hline
\end{tabular}


Acknowledgements. Support for this research was provided by the Korea Forest Service (S111314L100120, S111114L030100) and Korea Ministry of Environment (C314-00131-0408-0). We thank the Korea Forest Service and Korea Forest Research Institute for providing the 5th NFI data. We also thank Moonil Kim for technical support.

Edited by: J. Canadell

\section{References}

Ahn, J. S. and Chon, C. M.: Geochemical distributions of heavy metals and $\mathrm{Cr}$ behavior in natural and cultivated soils of volcanic Jeju island, Korea, Geosys. Engin., 13, 9-20, 2010.

Aizebeokhai, A. P.: Global warming and climate change: realities, uncertainties and measures, Int. J. Phys. Sci., 4, 868-879, 2009.

Bellassen, V., Viovy, N., Luyssaert, S., Le Maire, G., Schelhaas, M.J., and Ciais, P.: Reconstruction and attribution of the carbon sink of European forests between 1950 and 2000, Glob. Change Biol., 17, 3274-3292, 2011.

Boden, T. A., Marland, G., and Andres, R. J.: Global, regional, and national fossil-fuel $\mathrm{CO}_{2}$ emissions, Carbon Dioxide Information Analysis Center, Oak Ridge National Laboratory, US Department of Energy, Oak Ridge, TN, doi:10.3334/CDIAC/00001_V2011, 2011.

Calabi-Floody, M., Bendall, J. S., Jara, A. A., Welland, M. E., Theng, B. K. G., Rumpel, C., and Mora, M. L.: Nanoclays from an Andisol: extraction, properties, and carbon stabilization, Geoderma, 161, 159-167, 2011.

Chapin, F. S., Woodwell, G. M., Randerson, J. T., Rastetter, E. B., Lovett, G. M., Baldocchi, D. D., Clark, D. A., Harmon, M. E., Schimel, D. S., Valentini, R., Wirth, C., Aber, J. D., Cole, J. J., Goulden, M. L., Harden, J. W., Heimann, M., Howarth, R. W., Matson, P. A., McGuire, A. D., Melillo, J. M., Mooney, H. A., Neff, J. C., Houghton, R. A., Pace, M. L., Ryan, M. G., Running, S. W., Sala, O. E., Schlesinger, W. H., and Schulze, E.- D.: Reconciling carbon-cycle concepts, terminology, and methods, Ecosystems, 9, 1041-1050, 2006.

Chen, W., Chen, J., Liu, J., and Cihlar, J.: Approaches for reducing uncertainties in regional forest carbon balance, Global Biogeochem. Cy., 14, 827-838, 2000.

Choi, S., Lee, W. K., Kwak, D. A., Lee, S., Son, Y., Lim, K. H., and Saborowski, J.: Predicting forest cover changes in future climate using hydrological and thermal indices in South Korea, Clim. Res., 49, 229-245, 2011.

Choi, S. D. and Chang, Y. S.: Factors affecting the distribution of the rate of carbon uptake by forests in South Korea, Environ. Sci. Technol., 38, 484-488, 2004.

Dixon, R. K., Brown, S., Houghton, R. A., Solomon, A. M., Trexler, M. C., and Wisniewski, J.: Carbon pools and flux of global forest ecosystems, Science, 263, 185-191, 1994.

Fang, J., Guo, Z., Hu, H., Kato, T., Muraoka, H., and Son, Y.: Forest biomass carbon sinks in East Asia, with special reference to the relative contributions of forest expansion and forest growth, Glob. Change Biol., 6, 2019-2030, 2014.

Guo, Z., Fang, J., Pan, Y., and Birdsey, R.: Inventory-based estimates of forest biomass carbon stocks in China: a comparison of three methods, Forest Ecol. Manage., 259, 1225-1231, 2010.
Intergovernmental Panel on Climate Change (IPCC): Good practice guidance for land use, land-use change and forestry, available at: http://www.ipcc-nggip.iges.or.jp/, 2003.

Ito, A., Saigusa, N., Murayama, S., and Yamamoto, S.: Modeling of gross and net carbon dioxide exchange over a cool-temperate deciduous broad-leaved forest in Japan: analysis of seasonal and interannual change, Agr. Forest Meteorol., 134, 122-134, 2005.

Jandl, R., Lindner, M., Vesterdal, L., Bauwens, B., Baritz, R., Hagedorn, F., Johnson, D. W., Minkkinen, K., and Byrne, K. A.: How strongly can forest management influence soil carbon sequestration?, Geoderma, 137, 253-268, 2007.

Kang, Y.: Japan's exploitation of Korean forests and Korean resistance, Forests and Culture, 7, 6-19, 1998 (in Korean).

Kim, C.: Mass loss rates and nutrient dynamics of decomposing fine roots in a sawtooth oak and Korean pine stands, Korean J. Ecol., 25, 235-239, 2002.

Korea Forest Research Institute: Study on the basis of forest carbon accounting in Korea, Korea Forest Service, Korea, 2010 (in Korean).

Korea Forest Research Institute: The 5th national forest inventory report, Korea Forest Research Institute, Korea, 2011 (in Korean).

Korea Forest Service: Forestry statistics, Korea Forest Service, Korea, 1974 (in Korean).

Korea Forest Service: Forestry statistics, Korea Forest Service, Korea, 1985 (in Korean).

Korea Forest Service: Forestry statistics, Korea Forest Service, Korea, 1988 (in Korean).

Korea Forest Service: Statistical yearbook of forestry, Korea Forest Service, Korea, 1997 (in Korean).

Korea Forest Service: Statistical yearbook of forestry, Korea Forest Service, Korea, 2000 (in Korean).

Korea Forest Service: Statistical yearbook of forestry, Korea Forest Service, Korea, 2002 (in Korean).

Korea Forest Service: Statistical yearbook of forestry, Korea Forest Service, Korea, 2005 (in Korean).

Korea Forest Service: Table of tree volume/mass and yield table, Korea Forest Service, Korea, 2009 (in Korean).

Korea Forest Service: Statistical yearbook of forestry, Korea Forest Service, Korea, 2010 (in Korean).

Korea Forest Service: Statistical yearbook of forestry, Korea Forest Service, Korea, 2011 (in Korean).

Korea Forest Service: Statistical yearbook of forestry, Korea Forest Service, Korea, 2012 (in Korean).

Korea Forest Service: Statistical yearbook of forestry, Korea Forest Service, Korea, 2013 (In Korean).

Krinner, G., Viovy, N., Noblet-Ducoudré, N., Ogée, G., Polcher , J., Friedlingstein, P., Ciais, P., Sitch, S., and Prentice, I. C.: A dynamic global vegetation model for studies of the coupled atmosphere-biosphere system, Global Biogeochem. Cy., 19, 133, 2005.

Kurz, W. A. and Apps, M. J.: A 70-year retrospective analysis of carbon fluxes in the Canadian forest sector, Ecol. Appl., 9, 526547, 1999.

Kurz, W. A., Apps, M. J., Webb, T. M., and McNamee P. J.: Carbon budget of the Canadian forest sector: phase I (Inf. Rep. NOR-X326), Northern Forestry Centre, Canada, 1992.

Kurz, W. A., Dymond, C. C., White, T. M., Stinson, G., Shaw, C. H., Rampley, G. J., Smyth, C., Simpson, B. N., Neilson, E. T., Trofymow, J. A., Metsaranta, J., and Apps, M. J.: CBM-CFS3: a 
model of carbon-dynamics in forestry and land-use change implementing IPCC standards, Ecol. Model., 220, 480-504, 2009.

Lee, A. R., Noh, N. J., Yoon, T. K., Lee, S. K., Seo, K. W., Lee, W. K., Cho, Y., and Son, Y.: Estimation of forest soil carbon stocks with Yasso using dendrochronological approach, J. Korean For. Soc., 98, 791-798, 2009 (in Korean).

Lee, M. A., Lee, W. K., and Song, C. C.: Spatio-temporal change prediction and variability of temperature and precipitation, J. GIS Assoc. Korea, 15, 267-278, 2007 (in Korean).

Li, X., Yi, M. J., Son, Y., Jin, G., and Han, S. S.: Forest biomass carbon accumulation in Korea from 1954 to 2007, Scand. J. Forest Res., 25, 554-563, 2010.

Liski, J., Palosou, T., Peltoniemi, M., and Sievänen, R.: Carbon and decomposition model Yasso for forest soils, Ecol. Model., 189, $168-182,2005$

Liski, J., Lehtonen, A., Peltoniemi, M., Eggers, T., Muukkonen, P., and Mäkipää, R.: Carbon accumulation in Finland's forests 1922-2004 - an estimate obtained by combination of forest inventory data with modelling of biomass, litter and soil, Ann. For. Sci., 63, 687-697, 2006.

Liu, J., Peng, C., Apps, M., Dang, Q., Banfield, E., and Kurz, W.: Historic carbon budgets of Ontario's forest ecosystems, Forest Ecol. Manage., 169, 103-114, 2002.

Luyssaert, S., Ciais, P., Piao, S. L., Schulze, E. D., Jung, M., Zaehle, S., Schelhaas, M. J., Reichstein, M., Churkina, G., Papale, D., Abril, G., Beer, C., Grace, J., Loustau, D., Matteucci, G., Magnani, F., Nabuurs, G. J., Verbeeck, H., Sulkava, M., van der Werf, G. R., Janssens, J. A., and members of the Carboeurope-IP Synthesis Team: The European carbon balance. Part 3: forests, Glob. Change Biol., 16, 1429-1450, 2010.

Millikin, C. S. and Bledsoe, C. S.: Biomass and distribution of fine and coarse roots from blue oak (Quercus douglasii) trees in the northern Sierra Nevada foothills of California, Plant Soil, 214, 27-38, 1999.

Nabuurs, G.-J., Schelhaas, M.-J., Mohren, G. M. J., and Field, C. B.: Temporal evolution of the European forest sector carbon sink from 1950 to 1999, Glob. Change Biol., 9, 152-160, 2003.

Noh, N. J.: Carbon and nitrogen dynamics in a natural Pinus densiflora forest with different stand densities, Ph.D. thesis, Korea University, Korea, 2011.

Noh, N. J., Kim, C., Bae, S. W., Lee, W. K., Yoon, T. K., Muraoka, H., and Son, Y.: Carbon and nitrogen dynamics in a Pinus densiflora forest with low and high stand densities, J. Plant Ecol., 6, 368-379, 2013.

Nothdurft, A., Wolf, T., Ringeler, A., Böhner, J., and Saborowski, J.: Spatio-temporal prediction of site index based on forest inventories and climate change scenarios, Forest Ecol. Manage., 279, 97-111, 2012.

Pan, Y., Birdsey, R. A., Fang, J., Houghton, R., Kauppi, P. E., Kurz, W. A., Phillips, O. L., Shvidenko, A., Lewis, S. L., Canadell, J. G., Ciais, P., Jackson, R. B., Pacala, S. W., McGuire, A. D., Piao, S., Rautiainen, A., Sitch, S., and Hayes, D.: A large and persistent carbon sink in the world's forests, Science, 333, 988-993, 2011.

Park, C. W., Lee, J., Yi, M., Kim, C., Park, G. S., Kim, R. H., Lee, K. H., and Son, Y.: Estimation of change in soil carbon stocks of Pinus densiflora forests in Korea using KFSC model under RCP 8.5 climate change scenario, Clim. Change Res., 4, 77-93, 2013 (in Korean).
Park, G. S., Lim, J. G., Kim, D. H., and Ohga, S.: Net fine root carbon production in Quercus natural forest ecosystems of Korea, J. Fac. Agr. Kyushu U., 51, 57-61, 2006.

Park, G. S., Kang, G. N., Lee, S. J., Lee, H. G., Lee, S. Y., Chae, H. M., and Ohga, S.: Net fine root carbon production in Pinus densiflora, Pinus koraiensis, Larix kaempferi and Quercus acutissima stands, Gongju area, Chungnam province, Korea, J. Fac. Agr. Kyushu U., 55, 73-76, 2010.

Peltoniemi, M., Palosou, T., Monni, S., and Mäkipää, R.: Factors affecting the uncertainty of sinks and stocks of carbon in Finnish forests soils and vegetation, Forest Ecol. Manage., 232, 75-85, 2006.

Piao, S. L., Ito, A., Li, S. G., Huang, Y., Ciais, P., Wang, X. H., Peng, S. S., Nan, H. J., Zhao, C., Ahlström, A., Andres, R. J., Chevallier, F., Fang, J. Y., Hartmann, J., Huntingford, C., Jeong, S., Levis, S., Levy, P. E., Li, J. S., Lomas, M. R., Mao, J. F., Mayorga, E., Mohammat, A., Muraoka, H., Peng, C. H., Peylin, P., Poulter, B., Shen, Z. H., Shi, X., Sitch, S., Tao, S., Tian, H. Q., Wu, X. P., Xu, M., Yu, G. R., Viovy, N., Zaehle, S., Zeng, N., and Zhu, B.: The carbon budget of terrestrial ecosystems in East Asia over the last two decades, Biogeosciences, 9, 3571-3586, doi:10.5194/bg-9-3571-2012, 2012.

Shindo, H., Yoshida, M., Yamamoto, A., Honma, H., and Hiradate, S.: $\delta 13 \mathrm{C}$ values of organic constituents and possible source of humic substances in Japanese volcanic ash soils, Soil Sci., 17, 175-182, 2004.

Sitch, S., Smith, B., Prentice, I. C., Arneth, A., Bondeau, A., Cramer, W., Kaplan, J. O., Levis, S., Lucht, W., Sykes, M. T., Thonicke, K., and Venevsky, S.: Evaluation of ecosystem dynamics, plant geography and terrestrial carbon cycling in the LPJ dynamic global vegetation model, Glob. Change Biol., 9, 161-185, 2003.

Stinson, G., Kurz, W. A., Smyth, C. E., Neilson, E. T., Dymond, C. C., Metsaranta, J. M., Biosvenue, C., Rampley, G. J., Li, Q., White, T. M., and Blain, D.: An inventory-based analysis of Canada's managed forest carbon dynamics, 1990 to 2008, Ecol. Model., 222, 2333-2341, 2011.

Tak, K. and Wood, P. M.: The South Korean forest dilemma, Int. For. Rev., 9, 548-557, 2007.

Theng, B. K. G. and Yuan, G.: Nanoparticles in the soil environment, Elements, 4, 395-399, 2008.

United Nations Framework Convention on Climate Change (UNFCCC): Kyoto Protocol to the United Nations Framework Convention on Climate Change. Available at: http://www.unfccc.int, 1997.

Vanninen, P., Ylitalo, H., Sievänen, R., and Mäkelä, A.: Effects of age and site quality on the distribution of biomass in Scots pine (Pinus sylvestris L.), Trees, 10, 231-238, 1996.

Wang, G. G. and Klinka, K.: Use of synoptic variables in predicting white spruce site index, Forest Ecol. Manage., 80, 95-105, 1996.

Wang, S., Chen, J. M., Ju, W. M., Feng, X., Chen, M., Chen, P., and Yu, G.: Carbon sinks and sources in China's forests during 1901-2001, J. Environ. Manage., 85, 524-537, 2007.

Wutzler, T. and Reichstein, M.: Soils apart from equilibrium - consequences for soil carbon balance modelling, Biogeosciences, 4, 125-136, 2007, http://www.biogeosciences.net/4/125/2007/.

Yi, K., Park, C. W., Ryu, S.-R., Lee, K.-H., Yi, M.-J., Kim, C., Park, G.-S., Kim, R., and Son, Y.: Simulating the soil carbon dynamics 
of Pinus densiflora forests in central Korea, Scand. J. Forest Res., 28, 241-256, 2013.

Yoo, S., Kwak, D. A., Cui, G., Lee, W.-K., Kwak, H., Ito, A., Son, Y., and Jeon, S.: Estimation of the ecosystem carbon budget in South Korea between 1999 and 2008, Ecol. Res., 28, 1045-1059, 2013.
Yoon, T. K., Chung, H., Kim, R.-H., Noh, N. J., Seo, K. W., Lee, S. K., Jo, W., and Son, Y.: Coarse woody debris mass dynamics in temperate natural forests of Mt. Jumbong, Korea, J. Ecol. Field Biol., 34, 115-125, 2011.

Zhou, D., Zhao, S. Q., Liu, S., and Oeding, J.: A meta-analysis on the impacts of partial cutting on forest structure and carbon storage, Biogeosciences, 10, 3691-3703, doi:10.5194/bg-10-36912013, 2013. 